\title{
秎説
}

\section{免疫系と神経系をつなぐ分子 免疫系と神経系で働く新しい分子機構}

\author{
柳川 芳毅, 久保 靖憲, 松本真知子, 富樫 廣子
}

要約 : 免疫系と神経系との間には相互調節機構が存在 する．神経系による免疫系制御の1つとして，アドレ ナリン受容体を介した樹状細胞（抗原提示細胞）の機 能調節があげられる。ノルアドレナリンやアドレナリ ンは， $\alpha_{2}$ 受容体を介して樹状細胞の抗原取り込みを 促進し， $\beta$ 受容体を介してサイトカイン産生バランス を調節する。アドレナリン $\beta$ 受容体を介したシグナル は，炎症性サイトカインの産生を抑制するが，アレル ギー増悪因子であるインターロイキン - 33 の産生を上 昇させる．このサイトカイン産生バランスの変化は, ストレス時における免疫力低下とアレルギー性疾患の 増悪に関係していると推察される。一方, 免疫系によ る神経系制御の 1 つとして, Toll 様受容体 (TLR) 7 を 介した文脈的恐怖記憶の強化があげられる。この現象 は, ウイルス感染時の状況を, 好ましくない状況とし て記憶し，その状況を回避するための機構を反映して いるのかもしれない，免疫系と神経系は情報伝達物質 や受容体を共有し，それらの分子を介して互いに連携 し, 免疫反応と危険回避のための行動を併せた広い意 味での生体防御において重要な役割を果たしていると 考えられる。

\section{1.はじめに}

免疫系と神経系は互いに連携し, 生体の恒常性維持 において重要な役割を果たしている。また，免疫系と 神経系における相互調節機構に異常が起これば, 様々 な疾患の発症につながると考えられる。免疫系と神経 系における相互調節機構については，これまで多くの 研究が成されてきたが，それぞれが複雑なシステムに よって制御されているため, 未だ解明されてない分子 機構が存在すると思われる。筆者はこれまで，おもに
免疫系の領域において樹状細胞（抗原提示細胞）の機 能に着目した研究を進めてきた。最近では “免疫系と 神経系で働く新しい分子機構”に関するテーマに取り 組んでいる。 このテーマに対し, “免疫系からのアプ ローチ”と“神経系からのアプローチ”を行った結果, いくつかの興味深い知見を得ることができた。 そこで 本稿では，我々が新たに見出した知見と，この領域に おける最近の動向をあわせて, 免疫系と神経系で働く 新しい分子機構について概説する。

\section{2. アドレナリン受容体を介した免疫系の制御}

\section{1）ストレスによる免疫機能の調節}

現代社会におけるストレスは様々な疾患の病態に関 係していると考えられる(1)，ストレスと疾患との関 係を分子レベルで解明し，それにもとづく治療法を確 立することは，ストレス社会と呼ばれる現代において 早急に取り組むべき課題である，免疫領域においては， ストレスが感染症やアレルギー性疾患などの増悪に関 係していることが示唆されている $(2,3)$. 一般的に, 短期ストレスは免疫反応を増強し, 長期 (慢性) ス卜 レスは免疫反応を抑制すると考えられている。慢性ス トレスによる免疫力の低下とそれに伴う感染症のリス ク上昇については, ヒトおよび動物実験において比較 的詳しく解析されている。一方，ストレスによる免疫 反応の増強については報告が少なく, そのメカニズム についても不明な点が多い.

生体がストレスを受けると交感神経－副腎髄質系か らノルアドレナリンおよびアドレナリンが分泌され, 緊急事態に対する様々な生理反応が誘導される。 また, ノルアドレナリンやアドレナリンは, 免疫細胞におけ る炎症性サイトカインの産生を抑制することが知られ

\footnotetext{
キーワード：アドレナリン受容体, サイトカイン, Toll 様受容体, 文脈的恐怖記憶

北海道医療大学 薬学部 薬理学講座 病態生理学（广061-0293 北海道石狩郡当別町金沢 1757)

E-mail: yanagawa@hoku-iryo-u.ac.jp 原稿受領日：2012 年 10 月 9 日, 依頼原稿

Title: Molecular mechanisms involved in the interaction between the immune system and nervous system

Author: Yoshiki Yanagawa, Yasunori Kubo, Machiko Matsumoto, Hiroko Togashi
} 
ており，このことが慢性ストレスによる免疫力低下の 一因と考えられている，本章では，神経系による免疫 系の制御機構の 1 つとして, アドレナリン受容体を介 した免疫細胞の機能調節について解説する。なお， ス トレスによる視床下部一下垂体－副腎皮質系を介した 免疫抑制機構については他の総説を参照されたい.

\section{2）アドレナリン受容体を介した樹状細胞の抗原取り}

\section{込みの促進}

樹状細胞は, 強力な抗原提示細胞であり, 免疫機構 に扮ける監視役として全身に分布し, 免疫反応の始動 および調節に重要な役割を果たしている $(4,5)$. 病原 体が生体内へ侵入すると, 樹状細胞がいち早くそれを 察知し, 病原体抗原を取り込み $\mathrm{T}$ 細胞に提示し獲得免 疫反応が誘導される. また, 樹状細胞は Toll 様受容体 （TLR）などのパターン認識受容体を介して病原体構 造を認識し, 炎症性サイトカインの産生を誘導する。 ノルアドレナリンやアドレナリンは, 樹状細胞におけ る炎症性サイトカインの産生を $\beta$ 受容体を介して抑制 することが報告されているが $(6,7)$, それ以外の作用 についてはほとんど解明されていない.
最近，筆者らは樹状細胞の抗原取り込みが，ノルア ドレナリンによって数分以内に著しく促進されること を見出した(8). 各種受容体サブタイプに対するアゴ ニストおよびアンタゴニストを用いた実験から，ノル アドレナリンは $\alpha_{2}$ 受容体を介して樹状細胞の抗原取 り达みを促進すると考えられる(8)。ささらに，この抗 原取り达みには PI3K-Akt 経路の活性化が関与してい ることが示唆された（図1).

\section{3）アドレナリン受容体を介した抗原取り込み促進の}

\section{意義}

神経系における情報伝達は, 神経伝達物質の一過性 の放出によって調節されている，従って，免疫系の制 御においても神経系による短期の調節機構が存在する と思われる，急性ストレスによる交感神経系からの一 時的なノルアドレナリンの放出は, 樹状細胞の抗原取 り込みを速やかに促進すると考えられる．樹状細胞に よる抗原取り込みは, 獲得免疫の誘導において必須の プロセスであることから，この現象は短期ストレスが 免疫反応を増強することを説明するメカニズムの $1 つ$ であると推察される.

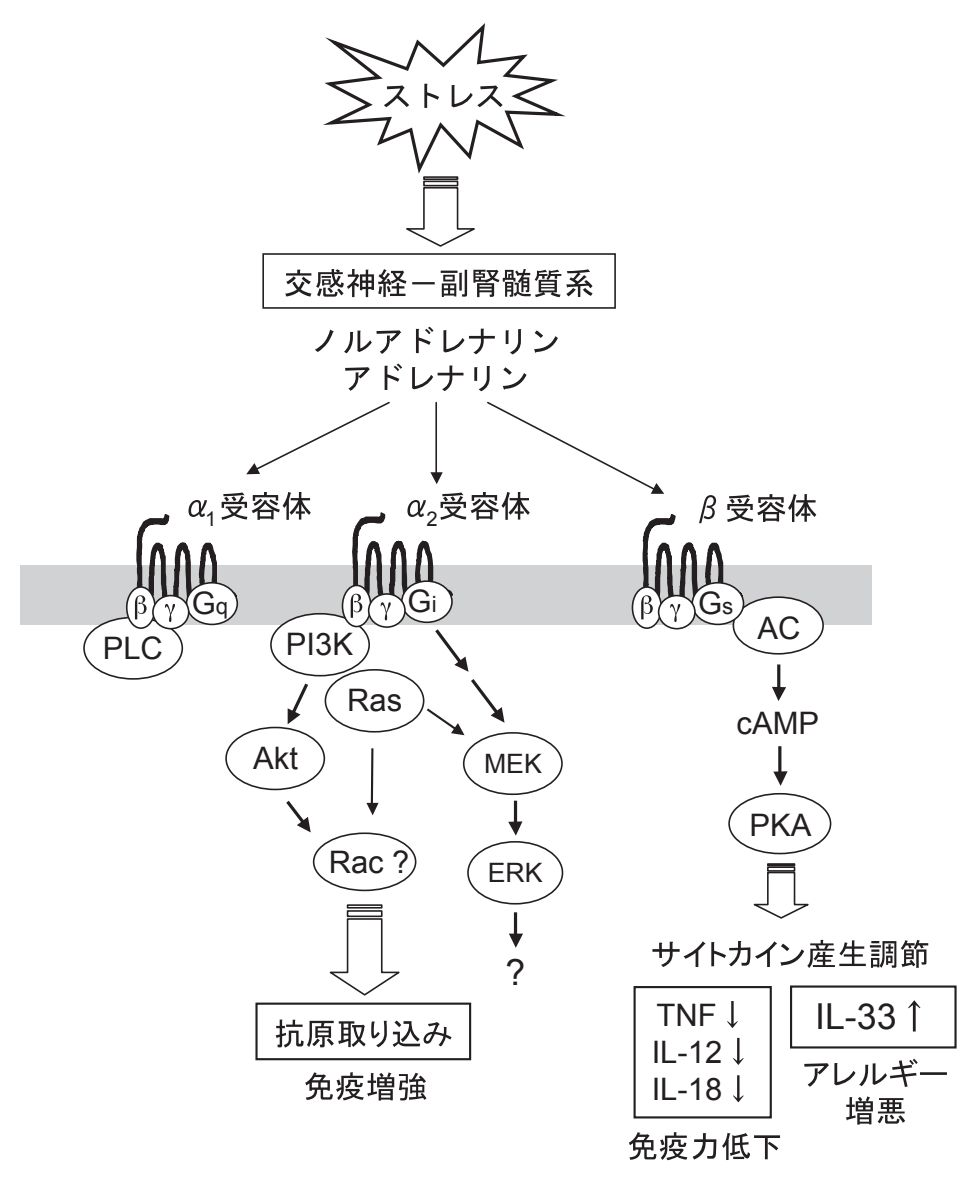

図 1 ストレスによる樹状細胞の機能調節（想定図）

ノルアドレナリンやアドレナリンは, $\alpha_{2}$ 受容体を介して樹状細胞の抗原取り込みを速やかに促進し，その一方で $\beta$ 受容体を介してサイトカイン 産生バランスを調節していると考えられる. TNF, IL-12, IL-18 の低下はストレスによる免疫力低下に関与し, IL-33の上昇はストレスによる アレルギ一性疾患の増悪に関与していると推察される. 図は想定されるシグナル経路を単純化したものであり, 実際にはより複雑な経路によっ て制御されていると考えられる。 
創傷部位においては，皮膚のバリアー機能の損傷に より病原体の侵入が起こるが，創傷ストレスは交感神 経系からのノルアドレナリンの放出を誘導すると報告 されている (9)。従って, 実際の生体において創傷部 位に分布する樹状細胞は, 病原体認識と同時にノルア ドレナリンからの刺激を受けていると思われる，樹状 細胞を TLRリガンドで刺激すると, 一時的に抗原取り 込みが上昇することが報告されており，この現象は獲 得免疫の誘導において重要であると考えられる (10). このTLR 刺激による抗原取り込みの上昇は, ノルアド レナリンによってさらに増強された(8)。従って, 創 傷とそれにともなう病原体侵入の際に, TLR とアドレ ナリン $\alpha_{2}$ 受容体を介したシグナルは協調的に作用し， 抗原取り込みを促進していると推察される.

\section{4）アドレナリン受容体を介したアレルギー増悪因子 IL-33 の産生増強}

インターロイキン (IL) -33 は IL-1 サイトカインフ アミリーに属する新しい炎症性サイトカインである (11)． IL-33 の受容体である ST2 は, T helper 2 (Th2) 細胞, 肥満細胞, 好塩基球, 好酸球などの $\mathrm{Th} 2$ 関連細 胞に発現し，これらの細胞機能の活性化に関与してい る. 従って, IL-33 は Th2 関連細胞を介した寄生虫な どに対する免疫反応を促進していると考えられる，そ の一方で，IL-33 はアレルギー性疾患に扔いて増悪因 子として働くことが示されている (12). IL-33 と同じ く IL-1 ファミリーに属する IL-18 はTh1 反応 (細胞性 免疫）を促進するのに対し， IL-33 は Th2 反応を促進 することから，これらのサイトカインの産生バランス は病原体に対する免疫反応の制御と免疫疾患の病態生 理において重要な意味を持つと考えられる。また, IL-33 は中枢神経系を含む様々な組織において発現し ているが，その発現調節機構については不明な点が多 い(13).

最近筆者らは, 樹状細胞の菌体成分認識にともなう 遺伝子発現の変化に対するノルアドレナリンの影響に ついて，マイクロアレイ法を用いて網羅的に解析した。 その結果, LPS (TLR4 リガンド) 刺激下において, ) ルアドレナリンが樹状細胞に打ける IL-33 発現を劇的 に上昇させることを見出した(14)，その一方で，ノル アドレナリンは, IL-1 $\beta$ および IL-18の発現を減少さ せた。 また，アドレナリンはノルアドレナリンより低 い用量で IL-33 産生を上昇させた．各種アドレナリン 受容体に対するアゴニストおよびアンタゴニストを用 いた実験から，IL-33の産生増強作用は，おもに $\beta_{2}$ 受 容体を介していると考えられる。ささらに，IL-33の産 生増強には細胞内 cAMP の上昇と PKA の活性化が関
与していることが示唆された（図 1)。 その後, マクロ ファージにおいても同様の機構によって IL-33 の発現 が増強されることが報告された(15).

5）アドレナリン受容体を介した IL - 33 産生増強の意義

気管支ぜん息やアトピー性皮膚炎などのアレルギー 性疾患は，ストレスによって症状が悪化すると考えら れるが，その詳細なメカニズムについては解明されて いない(16)。先に述べたように，生体がストレスを受 けると交感神経－副腎髄質系よりノルアドレナリンお よびアドレナリンが分泌され，これらのカテコールア ミンは樹状細胞やマクロファージに扔ける炎症性サイ トカインの発現を抑制する $(6,7)$ 。これとは逆に, ノ ルアドレナリンおよびアドレナリンは樹状細胞やマク ロファージにおけるIL-33 の発現を増強する $(14,15)$. IL-33 はアレルギー性疾患において増悪因子として働 くことが示唆されており，実際ヒトにおいて，IL-33 遺伝子の多型とアレルギー性疾患との間に相関性が見 出されている(17)。従って，ストレスによるアレルギ 一性疾患の増悪には, ノルアドレナリンやアドレナリ ンによる IL-33 の産生増強が関係している可能性があ る.

アドレナリン $\beta$ 受容体アゴニストは, $\mathrm{cAMP}$ の上昇 を介して気管支平滑筋を弛緩することから，気管支ぜ ん息の治療薬（気管支拡張薬）として広く用いられて いる. しかしながら，気管支ぜん息患者への長期作用 型アドレナリン $\beta$ 受容体アゴニストの投与は, 重症気 管支ぜん息の悪化や気管支ぜん息関連死の増加を招く ことがメタアナリシスにより示されている(18). 一方, 気管支ぜん息は代表的なアレルギー性疾患であり，

IL-33 はその増悪因子であると考えられる，樹状細胞 に扔ける IL-33 産生はアドレナリン $\beta$ 受容体アゴニス トによって著しく増強されることから (14), このこと がアドレナリン $\beta$ 受容体アゴニストの投与による気管 支ぜん息の増悪と関係しているのかもしれない.

\section{TLRを介した神経系の制御}

\section{1）TLRを介した中枢神経機能の調節}

TLR は, 免疫系における代表的なパターン認識受容 体で, 病原体の分子パターンに結合し, 自然免疫反応 を誘導する．TLRは自然免疫反応のみならず，その後 の獲得免疫反応の誘導においても重要な役割を果たし ている. 哺乳類に抒いては少なくとも 13 種類以上の TLR メンバーが存在し, 様々な病原体分子パターンを 認識することができる. TLRは扔もにマクロファージ や樹状細胞などの自然免疫系の細胞に発現しているが, 中枢神経系にも発現していることが示されている(19). 
最近, TLR3 欠損マウスにおいて海馬依存性の作業記 憶が強化され, その一方で扁桃体関連行動に障害が起 こることが報告された (20)。すなわち，TLR3 は海馬 依存性作業記憶と扁桃体関連行動の調節に関与してい ると考えられる. しかしながら，他の TLRメンバーの 中枢神経に扔ける役割については未だ不明な点が多い.

I 型インターフェロン（IFN- $\alpha$ や IFN- $\beta)$ は, 抗ウ イルス活性掞よび抗腫瘍活性を有し, 臨床においては ウイルス性肝炎や悪性腫瘍の治療に用いられている (21)。一方, I 型 IFN は精神神経系において様々な副 作用を引き起こすことが知られている。実際に, 高用 量の IFN- $\alpha$ は急性錯乱状態を誘発し, IFN - $\alpha$ の長期 投与はうつ様症状を誘導することが報告されている (22)。このように, I 型 IFN は中枢神経機能に対して 何らかの影響を及ぼすと考えられるが，その詳細なメ カニズムや生理的意義についてはほとんど明らかにさ れていない.

TLR7 はウイルス由来一本鎖 RNA 認識し I 型 IFN の産生を誘導する。TLR7 を介した I 型 IFN の産生は, ウイルスに対する免疫反応において重要な役割を果た している.一方, TLR7は脳内においても発現してい るが中枢神経機能における役割については解明されて いない(19)。そこで我々は, TLR7 の活性化とそれに
伴う I 型 IFN の産生が情動応答に与える影響について 検討した。 その結果, マウス文脈的恐怖条件付け試験 において, TLR7 が条件恐怖に対する行動応答の強化 に関与することを見出したので以下に示す.

\section{2）TLR7 を介した文脈的恐怖記憶の強化}

マウス文脈的恐怖条件付け試験を用いて，恐怖記憶 におけるTLR7 の役割について, TLR7 リガンド (イミ キモド）と TLR7 欠損マウスを使用して解析した (23). 恐怖条件付けの 4 時間前に TLR7 リガンドを投与した 場合, 文脈的恐怖記憶は有意に増強された。一方, TLR7 欠損マウスにおいて, このような増強作用は認 められなかった。また, TLR7リガンドは恐怖条件付 け直後の記憶の獲得に対して影響を示さなかった。従 って, TLR7 は文脈的恐怖記憶の固定強化に関与して いると考えられる．また，TLR7リガンドによる恐怖 記憶の強化は, 恐怖条件付けの 5 日後においても認め られた。従って, TLR7を介した中枢神経系における 作用は，長期にわたって維持されると考えられる。一 方, 恐怖条件付けの後に TLR7 リガンドを投与した場 合, 恐怖記憶の形成に影響は認められなかった。すな わち, 恐怖条件付けの時点における TLR7を介した反 応が恐怖記憶の強化に重要であると思われる.

恐怖記憶の形成過程には海馬が関係していると考え

A)

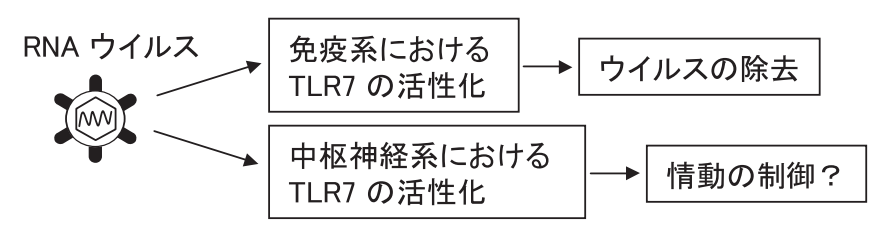

B)

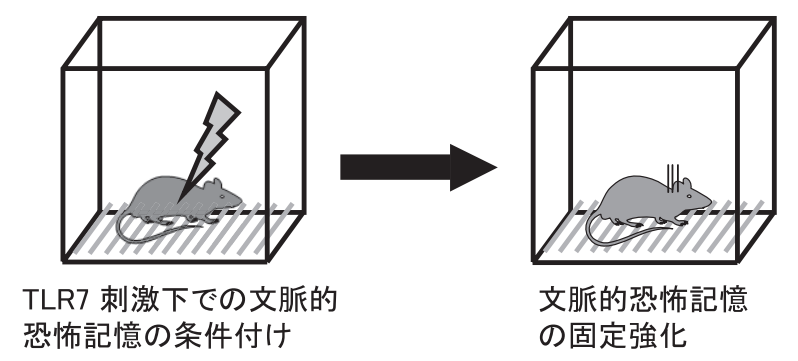

C)

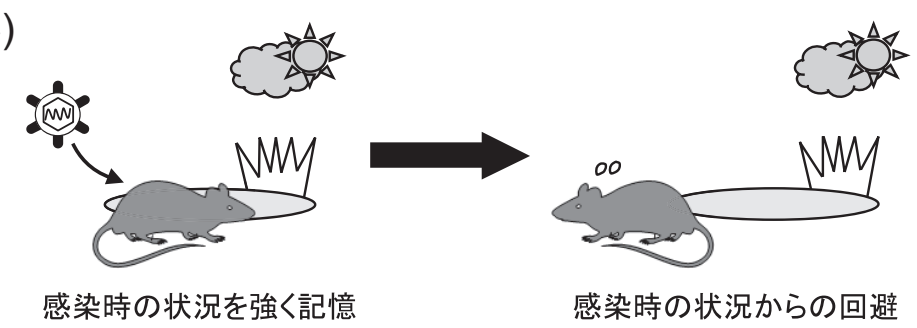

図 2 Toll 様受容体 (TLR) 7 刺激による中枢神経機能の調節とその意義（想定図）

免疫系において TLR7 は, ウイルス構造を認識し抗ウイルス反応を誘導する (A). その一方で, TLR7 は中枢神経系において文脈的恐怖記憶の 固定強化に関与していると考えられる (B). TLR7による文脈的恐怖記憶の固定強化は, ウイルス感染時の状況を強く記憶し, その状況を回避 するための機構を反映しているのかもしれない（C). 図は想定される可能性を示すものであり今後さらなる解析の必要がある. 
られているが，TLR7リガンドの投与によって，海馬 におけるIFN- $\alpha$ の発現は有意に増加した（投稿中）。 さらに，海馬に打ける TLR7 の発現は，脳全体と比較 して有意に高いことが見出された。一方，TLR7はア ストロサイトやミクログリアに発現しており，これら の細胞は I 型 IFN を産生することが報告されている (24,25)。また，アストロサイトは海馬において多く 存在することが示されている(26). 従って, アストロ サイトなどの TLR7 を発現する細胞が I 型 IFN を産生 することによって, 海馬機能が調節されているのかも しれない。また，TLR7を介した作用には，I 型 IFN 以外のサイトカインや未知の分子が関与している可能 性があり, 今後詳細に解析していく必要がある.

\section{3）TLR7 を介した恐怖記憶増強の意義}

TLRは様々な病原体を認識し, 病原体に対する免疫 反応において重要な役割を果たしている，免疫系にお いて TLR7 は, ウイルス構造を認識し抗ウイルス反応 を誘導する (図 2A)。免疫系での役割に加え, TLR7 は 中枢神経系において文脈的恐怖記憶の固定強化に関与 していると考えられる（図 2B）。この現象は，ウイル 又感染時の状況を, 好ましくない状況として強く記憶 し，その状況を回避するための機構を反映しているの かもしれない（図 2C)，従って，TLR7 の中枢神経系 に抢ける役割やその分子機構を詳細に解析することは， 免疫系と神経系が連携した生体防御機構における新し い概念の発見につながる可能性がある.

\section{4. おわりに}

本稿では，免疫系と神経系で働く新しい分子機構に ついて最近の我々の知見を中心に概説した。神経系に よる免疫系制御として，アドレナリン受容体を介した 樹状細胞の機能調節があげられる．樹状細胞は免疫反
応の始動および制御において重要な役割を果たしてい ることから，その機能制御に抢いてストレスに対する 交感神経 - 副腎髄質系の反応機構が関与していること は興味深い. 一方, 免疫系による神経系制御として, TLR7 を介した文脈的恐怖記憶の固定強化があげられ る. 文脈的恐怖記憶には海馬が重要であることから, 海馬に分布する TLR7 陽性細胞が海馬機能の調節に関 与している可能性がある。すなわち, 免疫系と神経系 は情報伝達物質や受容体を共有し，それらの分子を介 して互いに連携し, 免疫応答と危険回避のための行動 応答を併せた広い意味での生体防御において重要な役 割を果たしていると考えられる。

\section{文献}

1) Chrousos GP, et al. Nat Rev Endocrinol. 2009;5:374-381.

2) Glaser R, et al. Nat Rev Immunol. 2005;5:243-251.

3) Segerstrom SC, et al. Psychol Bull. 2004;130:1-37.

4) Banchereau J, et al. Nature. 1998;392:245-251.

5) Yanagawa Y, et al. J Immunol. 2007;178:6173-6180

6) Goyarts E, et al. Exp Dermatol. 2008;17:188-196.

7) Maestroni GJ. J Neuroimmunol. 2002;129:106-114.

8) Yanagawa Y, et al. J Immunol. 2010;185:5762-5768.

9) Gosain A, et al. J Trauma. 2006;60:736-744.

10) West MA, et al. Science. 2004;305:1153-1157.

11) Smith DE, et al. J Leukoc Biol. 2011;89:383-392.

12) Liew FY, et al. Nat Rev Immunol. 2010;10:103-110.

13) Schmitz J, et al. Immunity. 2005;23:479-490.

14) Yanagawa $Y$, et al. Brain Behav Immun. 2011;25:1427-1433

15) Polumuri SK, et al. J Immunol. 2012;189:50-60.

16) Wright RJ, et al. J Allergy Clin Immunol. 2005;116:1301-1306.

17) Gudbjartsson DF, et al. Nat Genet. 2009;41:342-347.

18) Salpeter SR, et al. Ann Intern Med. 2006;144:904-912.

19) Mishra BB, et al. J Neuroimmunol. 2006;181:46-56.

20) Okun E, et al. Proc Natl Acad Sci U S A. 2010;107:15625-15630.

21) Hauser P, et al. Mol Psychiatry. 2002;7:942-947.

22) Raison CL, et al. CNS Drugs. 2005;19:105-123.

23) Kubo Y, et al. Pharmacol Biochem Behav. 2012;102:495-501.

24) Butchi NB, et al. Glia. 2010;58:650-664.

25) van Heteren JT, et al. Glia. 2008;56:568-578.

26) Butenko O, et al. PLoS One. 2012;7:e39959. 